\title{
FIFTH INTERNATIONAL WEST AFRICAN CONFERENCE
}

\begin{abstract}
CCIENTISTS working in the several territories of $\$$ West Africa were long hampered by lack of opportunities for contact with one another. Contiguity of territory enabled the French to extend much of their work over the whole or greater part of French West Africa; but studies in the separate British, Spanish and Portuguese areas lacked correlation. A very important function is thus served by the International West African Conference, which meets every second year, alternating between British, French, Spanish and Portuguese territories. The fifth" conference was held at Abidjan (Côte d'Ivoire) during December 7-10, 1953, followed by excursions during December 11-19. Difficulties of accommodation, not the least being space on air lines, necessitated the participation being restricted to official delegates; but those present represented a wide range of interests and regions.
\end{abstract}

The conference met under the presidency of Prof. G. Mangenot, director of the Institut de Recherche Scientifique et d'Etudes Tropicales of the Office de la Recherche Scientifique Outre-Mer, and most of the meetings were held at the Research Station of the Institut at Adjopodoumé some $18 \mathrm{~km}$. from Abidjan. Other meetings were held at the Museum and Research Station in Abidjan of the Institut Français d'Afrique Noire, the headquarters director of which is Prof. Th. Monod (Dakar). The smooth running of the conference owed everything to the organizing ability of M. J. L. Tournier, of the Institut Français d'Afrique Noire, who acted as secretary.

Delegates included a dozen from British West African territories and two from Britain (Profs. C. Daryll Forde and L. Dudley Stamp), and the conference opened with a gathering at the Palace of the Governor, followed in the evening by a brilliant and lavish reception at Adjopodoumé attended by leading citizens, both African and European, of Abidjan.

The working sections were those of zoology, botany (including forestry), geography (including geology) and ethnology-sociology (including economics). For some sessions the last two met jointly, and papers of general interest were read to plenary meetings.

It would be difficult to speak too highly of the lavish hospitality of the French hosts. A conference where delegates have no need of money at all, their every wish being anticipated by a systern of vouchers, must be almost unique. The insight given into the cultural life of a remarkable tropical city with fourteen thousand white inhabitants was a revelation to many of the delegates long familiar only with their own territories. The conference was in other ways ideal in that it gave abundant opportunities for discussion amid delightful surroundings, and local excursions arranged for all interests formed a pleasant prelude to the two long excursions. Of the latter, one studied the ecology and forestry of the coastal belt, and the other undertook the long journey across to the Liberian border and the eventual ascent of the massif of Nimba.

The conference revealed in a striking way the large volume of fundamental research now in progress in West Africa. In the French territories this is now focused by the Institutes; in the British territories the influence of the University Colleges of the Gold Coast and Ibadan is very marked. Young enthusiastic scientists, not overburdened with routine teaching, are bringing to bear on African problems techniques acquired in universities all over the world. At present, those of European descent play the leading part; but Africans are beginning to take their places in the ranks of the research workers. Detailed studies ranging from the distribution of population, so bafflingly irregular, and the ecology of disease to the measurement of evaporo-transpiration and the economics of fisheries cannot fail to throw light on the innumerable problems which at present hinder the development of tropical Africa and at the moment make nonsense of 'planning'.

L. Dudley Stamp

\section{THE GOLGI APPARATUS}

\section{SYMPOSIUM OF THE ROYAL MICROSCOPICAL SOCIETY}

$\mathrm{O}^{\mathrm{N}}$ N May 5 the Royal Microscopical Society held a symposium on "The Golgi Apparatus". The opening address was made to a large gathering by the chairman for the morning session, Dr. L. Foulds, who directed attention to the present controversy regarding the intrinsic morphology of the Golgi apparatus.

The first speaker was Prof. J. Brontë Gatenby (Trinity College, Dublin), who expressed his gratitude to the Society for its recent award to him of an honorary fellowship. He then went on to review the various controversies which have been in vogue conceming the morphology of the Golgi apparatus. The most important controversy of all, he said, arose with the vacuome theory of the Parat school (1924-33); but this work has been discredited by many cytologists. It is significant that Parat's term 'lépidosome' instead of 'dictyosome' has not been used in the new great French text-book "Traité de Zoologie". With regard to the recent controversial views, held mainly by the
Oxford school, Prof. Gatenby said that on the whole, apart from their use of Parat's word lepidosome, he is in agreement with much that they have written about the structure of the Golgi apparatus of invertebrate cells. However, he cannot accept the view that the Golgi apparatus or network of vertebrate neurones is an artefact. Both Dr. T. A. Moussa and he have seen the network in living neurones, and this has been confirmed by the vital observations of the Americans Adamstone and Taylor. Similar networks have also been seen in living cells of the epididymis by Dr. A. J. Dalton and Mrs. M. Felix. In addition, these latter workers have supplied him with some remarkable electron micrographs which agree with his conception of the networks as being a series of vacuoles, compressed spaces and canals, to the walls of which a chromophile substance is attached.

Finally, Prof. Gatenby gave seven reasons why he believes that the Golgi dictyosomes of invertebrate cells may be regarded as being homologous with the 